\title{
Holding the Whip-Hand
}

\section{The Female Slaveholder in Myth and Reality}

\author{
Natalie Zacek \\ University of Manchester, Manchester, UK \\ natalie.a.zacek@manchester.ac.uk
}

\begin{abstract}
This article examines two female slaveholders, one real and one fictional, to explore the relationship between gender and slave management in both history and popular culture. Annie Palmer, the "White Witch of Rose Hall" plantation in Jamaica, although the creation of folklore and journalistic exaggeration, has functioned for a century and a half as a symbol not only of the evils of slavery but of the idea that female slaveholders' cruelty threatened the system of slavery in a way in which that practiced by males did not. In New Orleans, Delphine Lalaurie, an elite woman renowned for her elegance and piety, became a figure of monstrosity after a house fire of 1834 revealed that her French Quarter mansion held a chamber of horrors for the enslaved, and offered a similar example of the dangers of female power in slave societies. Examining these women's continuing presence both as historical figures and as characters in novels, television shows, and other creative productions, this article illuminates the strange career of the slaveholding woman, a figure execrated in her own era and misunderstood or ignored in contemporary historiography, yet simultaneously the subject over centuries of prurient cultural fascination.
\end{abstract}

\section{Keywords}

slavery - New Orleans - Jamaica - Annie Palmer - Delphine Lalaurie

\section{1 \\ Introduction}

In October 2013, Delphine Lalaurie rose from the dead. In the opening episode of Coven, the third series of the American Horror Story franchise, this New 
Orleanian, who had apparently spent almost two centuries buried alive after being forced to drink a potion granting her eternal life, was disinterred by the leader of a local coven, who hoped to use Lalaurie's sorcerous powers against a rival group of witches. ${ }^{1}$ This was most viewers' first encounter with the "Mad Madame," but in her native city she had never disappeared from view. Notorious in her own lifetime for her sadistic abuse of the enslaved people who worked at her townhouse at 1140 Royal Street, her story has long been incorporated into Crescent City folklore. Although the "Haunted House" has long been a private residence, it appears on every tourist map and walking tour of the French Quarter, and the corner of Royal and Governor Nicholls streets daily attracts loiterers who stare in fascination at the imposing but otherwise innocuous grey stone edifice. The house's current owners have made it clear that they would prefer that thrill-seekers leave them in peace, but even if they opened the mansion's doors to them, nothing within remains from the Lalaurie era, 1140 Royal having functioned as a school, a conservatory, a soup kitchen, and a boarding house before returning to private ownership in the mid-twentieth century. ${ }^{2}$

In sharp contrast, visitors to Rose Hall Plantation, outside Montego Bay, Jamaica, are encouraged to tour this Georgian "great house," and while some are lured by the residence's architectural grandeur and the rare antiques with which it is furnished, the majority seem to be drawn by its association with another female slaveholder who became infamous for her alleged cruelty to her slaves: Annie Palmer, the "White Witch of Rose Hall." Even those who opt out of the "Haunted Night Tour," which "venture[s] into the world of the White Witch," and is "not for the faint of heart," see places described as Palmer's bedroom (decorated in red, her "favourite colour"), her torture chamber, and her tomb. In reality, none of the furnishings at Rose Hall are original to the property, and while Delphine Lalaurie is a verified historical personage, the "White Witch" is primarily the creation of Herbert G. de Lisser, a Jamaican writer of mixed racial heritage who introduced her to the wider world in his 1929 novel, The White Witch of Rosehall, which remains the principal source of the narrative presented at the plantation. Nevertheless, the estate is one of the island's most popular tourist attractions, part of a luxurious resort development which

1 Tiffany A. Christian, "Using the Past to Recuperate the Present: The Authentic Evil of Madame Delphine Lalaurie in American Horror Story: Coven," Journal of Popular Culture $5^{2}$ (2019): 1101.

2 The Lalaurie house was last open to the public in the 1940s; at that time, visitors "explore[d] its great rooms and balconies, its halls and galleries and winding stairs with wide eyes and an appreciative shiver" (Jeanne de Lavigne, Ghost Stories of Old New Orleans [New York: Rinehart and Company, Inc., 1946], 248). 
includes conference facilities, shops, wedding venues, and a golf course. If a tourist visits any Jamaican plantation house, it will almost certainly be Rose Hall. $^{3}$

It is tempting to dismiss these stories, due to the ways in which they have been represented, and monetized, through touristic endeavors such as those described above, on the Internet via amateur videos with titles such as "Delphine Lalaurie: Monster of Royal Street," or in productions such as Ghost Hunters International's pseudo-scientific investigation of Rose Hall. ${ }^{4}$ But these women's stories have also inspired many writers, musicians, and other creatives for over a century. Before Delphine Lalaurie became internationally known through Coven, in which Kathy Bates won an Emmy for her portrayal, she lived on in ghost tales recounted by New Orleanian folklorists and amateur historians, and, more recently, in horror and mystery novels, a comic book series, an epic poem, several low-budget independent films, board and computer games, and a chamber opera. ${ }^{5}$ Annie Palmer has come to life not only in de Lisser's

3 "Rose Hall Great House Haunted Night Tour" (https://rosehall.com/tours/), accessed 16 June 2020; Rex Nettleford, et al., Rose Hall, Jamaica: Story of a People, a Legend, and a Legacy (Rose Hall, Jamaica: Rose Hall Ltd., 1973), 24; Felipe Smith, "The Economics of Enchantment: Two Montego Bay, Jamaica Great House Tours," in Lowell Fiet and Janette Becera, eds., Caribbean 2000: Cultural (Con)Fusion (San Juan: University of Puerto Rico Press, 2000), 25.

4 "Delphine Lalaurie: Monster of Royal Street" (https://www.youtube.com/watch?v=HKJE2J qkRrQ); "Ghost Hunters International: The Legend of Rose Hall," series 2, episode 13 (first aired 17 February 2010) (https://www.youtube.com/watch?v=PJ8Noa64ls4); both accessed 16 June 2020.

5 George Washington Cable, "The Haunted House in Royal Street," in Cable, Strange True Stories of New Orleans (New York: Charles Scribner's Sons, 1889) (https://www2.latech.edu/ bmagee/ louisiana_anthology/texts/cable/cable--haunted_house.html; accessed 16 June 2020); Henry C. Castellanos, "A Tale of Slavery Times," in Henry C. Castellanos, New Orleans As It Was: Episodes of Louisiana Life, ed. Judith Kelleher Schafer (Baton Rouge: Louisiana State University Press, 2006 [originally published 1895]), 52-62; Lyle Saxon, Fabulous New Orleans (Gretna, LA: Pelican Publishing Company, 1988 [originally published 1928]), 202-217. Lalaurie appears in the novels Papa La-Bas by John Dickson Carr (New York: Carroll \& Graf, 1998 [originally published 1968]); Fever Season by Barbara Hambly (New York: Bantam Books, 1998); L'Immortalite: Madame Lalaurie and the Voodoo Queen by T.R. Heinan (Tucson: Nonius LLC., 2012) and Demoness by Martin Kage (n.p.: Bad Day Books, 2016), in a comic book series anthologized in Serena Valentino's Nightmares and Fairytales: 1140 Rue Royale (San Jose, CA: SLG Publishing, 2009); in "Cacophony," a chamber opera by Jennifer N. Roberts (MA thesis, Bowling Green State University, 2014); in the epic poem The Lalaurie Horror by Jennifer Reeser (New Orleans: Saint James Infirmary Books, 2013); in the independent films The St. Francisville Experiment (Ted Nicolaou, 2000) and Trespassing (James Merendino, 2004); in the board game Evil Baby Orphanage, and in the computer game Deadtime Stories ("Delphine LaLaurie," Wikipedia [https://en.wikipedia.org/wiki/Delphine_LaLaurie], accessed 16 June 2020). 
eponymous novel, but in other works of fiction, several plays (including a musical), a ballet, pantomimes, and a song written and recorded by Johnny Cash, who owned a vacation house near Rose Hall. ${ }^{6}$

Given that Annie Palmer was not a real person, and that the past two centuries have seen little increase in the corpus of information regarding Delphine Lalaurie, what is it that attracts so many artists to these women's stories, and lures tourists to locations which retain no material traces of them? How have these legends influenced historical and cultural representations of the experience of slavery, whether in New Orleans, in Jamaica, or more broadly throughout the Atlantic world? And how have they contributed to both public and academic understandings of the experiences of white women as managers of enslaved people? This article draws upon the legends of Annie Palmer and Delphine Lalaurie to argue that their seemingly exceptional stories fit within a long-standing Anglo-American discourse that depicts women as inherently unsuited to the supervision of slaves, and that predicts that any society in which women can take on this role is in danger of collapse. Despite the contextual differences between these stories, with regard to geography and temporality, and the fact that one protagonist is real and the other fictional, their persistence in both historiography and popular culture reflects the uncomfortable questions they raise regarding gender and slavery. Neither Palmer nor Lalaurie could be considered typical female slaveholders, but their very atypicality calls into question long-standing ideas about the roles of white women within the "peculiar institution."

The "Wicked Slave-Holder" and the "Jamaica Termagant"

The "facts" of Annie Palmer's "life" begin with her birth circa 180o in revolutionary Saint-Domingue, to Irish and English parents, paralleling the experiences of Thomas Sutpen, the anti-hero of William Faulkner's Absalom, Absalom! When

6 Annie Palmer appears in the novels Jamaica White by Hal Underhill (New York: Bantam Books, 1969) and Voyager by Diana Gabaldon (New York, Delacorte Press, 1993); in the plays Ann Palmer of Rose Hall: A Drama in Three Acts by T.G. Wakeling (n.p.), The White Witch of Rose Hall by Archie Lindo (1945), and The White Witch of Rose Hall by Sol River (1998); in the pantomimes The Witch (Barbara Gloudon, 1975) and Miss Annie (Gloudon, 2002); in the ballet Rose Hall (Company Dance Theatre, 1994), in the musical White Witch (Jane Crichton, 2010); and in the song "The Ballad of Annie Palmer," on Johnny Cash's album Any Old Wind That Blows (Columbia Records, 1973). See Leah Rosenberg, "Tourism and the Birth of Jamaican Literature," Jamaica Journal 32 (2015), 51, and Laura Lomas, "Mystifying Mystery: Inscriptions of the Oral in the Legend of Rose Hall," Journal of West Indian Literature 6 (1994): 86. 
they died of yellow fever, the adolescent Annie was adopted by an African-born voodoo priestess, who trained her in sorcerous practices otherwise known only to people of African descent. ${ }^{7}$ Aged about twenty, Annie relocated to Jamaica and married John Palmer, the builder of the great house at Rose Hall; she allegedly murdered him, and did the same to her two subsequent spouses. ${ }^{8}$ Having inherited the estate and amassed a fortune from her three husbands, she chose not to marry again, and instead took lovers from among the estate's male slaves. When she tired of them, she would command other slaves to torture them to death in the great house's cellar, which she allegedly had fitted out as a dungeon. She was also rumored to dress in male attire and to ride at night around the countryside near Rose Hall, whipping any slave she encountered. According to de Lisser's novel, Annie was murdered in the course of the islandwide slave uprising of Christmas 1831, killed by a free man of color named Takoo, an obeah practitioner.

It is very unlikely that Annie Palmer ever existed. Rose Hall's first mistress, Rosa Kelly Palmer, was married four times, but there is no evidence that she murdered her husbands, practiced voodoo, or was the lover or torturer of enslaved men. John Palmer's great-nephew, John Rose Palmer, married a woman named Annie May Patterson, but she was born in Jamaica rather than Haiti, and was raised by her Scottish parents, not by an African mambo. John Rose Palmer died in 1827, of natural causes, and soon thereafter his widow sold her interest in the heavily indebted estate and moved away; she died in 1846, fifteen years after her supposed murder by Takoo. ${ }^{9}$ Annie Palmer's first depiction as a homicidal sorceress came in a ten-page pamphlet, "Legend of Rose Hall Estate," composed by a local newspaper editor, James Castello, and published in 1868 . This text, along with an equally sensational and heavily rehashed ver-

7 Although Hollywood films and pulp novels from the era of the American occupation of Haiti occasionally depict whites as voodoo practitioners, and elite white New Orleanians supposedly employed the "voodoo queen" Marie Laveau to use her powers to their benefit, Palmer is unique as being depicted as a white voodoo practitioner in the era of slavery (Jennifer Fay, "Dead Subjectivity: White Zombie, Black Baghdad," cR: The New Centennial Review 8 [2008], 85; John W. Blassingame, Black New Orleans, 1860-1880 [Chicago: University of Chicago Press, 1973], 5).

8 John Palmer built Rose Hall, but he died in 1797, several years before Annie's supposed birth ("Hon. John Palmer," Legacies of British Slave-Ownership [https://www.ucl.ac.uk/lbs/person/ view/2146644535], accessed 16 June 2020).

9 By 1830, the great house at Rose Hall was "unoccupied save by rats, bats, and owls"; it hosted several of the Irish medical missionary Hope Masterson Waddell's Presbyterian services for racially mixed congregations (Hope Masterson Waddell, Twenty-Nine Years in the West Indies and Central Africa: A Review of Missionary Work and Adventure, 1829-1858 [London: T. Nelson and Sons, 1863], 42). 
sion which appeared in 1911, appears to have been the principal inspiration for de Lisser's novel.

Like Palmer, Delphine Lalaurie was an elite slaveholding woman who was renowned for her beauty, but in contrast to the "White Witch," who was apparently viewed with suspicion within planter society long before evidence of her crimes emerged, for most of her life she was regarded as the finest flower of creole womanhood. Born circa 1775 in then-French New Orleans as Delphine Macarty, of French and Irish background, she married advantageously, first to Don Ramon Lopez y Angulo, a high-ranking Spanish royal officer, and then to Jean Blanque, a prominent financier and lawyer. She was celebrated not only as a lady of fashion and a gracious hostess, but as a living saint who devoted herself to charitable activities, particularly to nursing victims of the outbreaks of yellow fever which repeatedly devastated the city. But on 10 April 1834 Lalaurie's house, which she had purchased several years earlier, and which she inhabited with her third husband, French-born physician Louis Lalaurie, and her two daughters from her previous marriages, caught on fire; when the fire brigade, over the Lalauries' protests, broke down the door to the attic, they apparently discovered a chamber of horrors, in which a number of enslaved men and women were chained to the walls, suffering the effects of abuse which went well beyond the brutal punishments which law and custom sanctioned. According to the most lurid account, some of the captives were "strapped to makeshift operating tables ... some of the women had their stomachs sliced open and their insides wrapped about their waists. One woman had her mouth stuffed with animal excrement and then her lips were sewn shut ... One man hung in shackles with a stick protruding from a hole that had been drilled in the top of his head ... There were a few who clung to life ... like a woman whose arms and legs had been removed and another who had been forced into a tiny cage with all her limbs broken than [sic] set again at off angles."10 Other journalistic descriptions were less graphic, but they all emphasised that these people had been subjected to forms of abuse which even the most hardened slaveholders considered unacceptable, the revelation of which, they feared, would offer support to the nation's nascent abolitionist movement.

Word spread quickly through the city of the discovery at 1140 Royal Street, encouraging a mob of local men, mostly working-class European immigrants, to storm the house and to steal or destroy almost everything inside it, leaving it a shell, its walls daubed with "writings expressive of indignation."11 But the

10 Susan Perez Castillo, "'Stones in the Quarry' and Fiction in George Washington Cable's Strange True Stories of Louisiana," Southern Literary Journal 31 (1999): 159. 
Lalauries managed to escape, possibly with the assistance of Delphine's cousin August Macarty, the city's mayor, and are believed to have made their way to France, where Delphine apparently died sometime in the 1840s. Accounts of their experiences are contradictory; some describe the couple as living a life of luxury among Paris's haute bourgeoisie, and others assert that, when word of her crimes crossed the Atlantic, the Lalauries became outcasts, and spent the rest of their lives in poverty and obscurity.12

The crimes of the real Delphine Lalaurie and the fictitious Annie Palmer are specifically linked to the early $1830 \mathrm{os}$, a fraught moment in the history of Atlantic slavery. In Jamaica, Emancipation was on the horizon, while in the United States, the British example of parliamentary abolition inspired an increasingly influential anti-slavery movement. At such a time, lurid tales of slaveholders' cruelty could be, and were, mobilized as evidence that the "peculiar institution" was not, as its defenders claimed, a benevolent system based upon slaveowners' paternalistic care of their bondspeople, but instead permitted cruel or deranged individuals to indulge their sadistic appetites. But neither the West Indian colonies nor the American slave states were short of accounts of the inhumane practices of male slaveholders, so what factors caused these women to be seen as epitomizing the horrors of the institution?

Although even the most fervent anti-slavery activists were forced to admit that such abuses as those perpetrated by Delphine Lalaurie were highly unusual, they maintained that as long as slavery continued to exist such horrors would continue. The story of 1140 Royal Street, the gracious mansion whose elegant façade hid a torture chamber, was a perfect metaphor for the slave South, and abolitionists brought the case to national attention by reprinting excerpts from New Orleanian newspaper accounts and adapting the story for various audiences, including children. In an early issue of The Slave's Friend, the American Anti-Slavery Society's magazine aimed at young people, Lalaurie is the eponymous villain in the story "The Wicked Slave-Holder." The anonymous author emphasized her elite status by noting that "she was rich, and lived in a splendid house," and while s/he refrained from regaling young readers with

Early America (Princeton, NJ: Princeton University Press, 2016), 327; Katy Francis Morlas, "La Madame et la Mademoiselle: Creole Women in Louisiana, 1718-1865" (MA thesis, Louisiana State University, 2005), 119; “Summary," Providence Patriot, 3 May 1834.

12 Grace King, Creole Families of New Orleans (New York: The Macmillan Company, 1921), 373; Marie Louise Points, The Haunted House: Its Interesting History and a Strange Romance (Chicago: The Craig Press, 1893), 13; Robert Tallant, The Romantic New Orleanians (New York: E.P. Dutton \& Co., Inc., 1950), 152; "Epitaph-Plate of 'Haunted' House Owner Found Here: Marble Cutter's Discovery Starts New Talk of Madame Lalaurie," New Orleans TimesPicayune, 28 January 1941. 
the goriest details of the slaves' sufferings, $\mathrm{s} /$ he described them as having been "dreadfully beaten," "chained to the floor" or "tied to the ceiling," with their bodies "from head to foot ... covered with scars and sores." Coverage aimed at adult audiences depicted these atrocities as the "Horrid Fruits of Slavery," occurrences which, the abolitionist newspaper the Emancipator argued, "could have originated only in the spirit, and been perpetuated in the opportunity produced by American slavery." ${ }^{\prime 3}$ The English reformer Harriet Martineau reached similar conclusions, as described in her Retrospect of Western Travel (1838). Martineau visited New Orleans in 1836 , in the course of a lengthy trip through the United States, and heard of the Lalaurie case from acquaintances there. She conceded that Lalaurie's actions were highly atypical, but argued that they were "a revelation of what may happen in a slave-holding country, and can happen nowhere else." Lalaurie's behaviour might have been prompted by mental illness, but even if she were mad, Martineau claimed, "the insanity could have taken such a direction, and perpetrated such deeds nowhere but in a slave country." 14

In de Lisser's novel, which appeared almost a century later, Annie Palmer must die, not only for her own sins, but for those of Jamaican slavery, whose practitioners had been far less successful — or, perhaps, just less concernedthan those of the antebellum South in maintaining a façade of paternalism. ${ }^{15}$ By this logic, it is appropriate that she is murdered by an ex-slave-but Takoo too must perish; although he has rid the island of a monster, he has also committed violence against his social and racial superior, and he represents the frightening practice of obeah and the still more alarming threat of black uprising. ${ }^{16}$ It is the novel's hero, Robert Rutherford, a stolid and recently arrived Englishman, who rescues the estate from the menaces Annie and Takoo rep-

13 Kristin Nicole Huston, “'Something At Least Human': Transatlantic (Re)Presentations of Creole Women in Nineteenth-Century Literature and Culture" (PhD thesis, University of Missouri-Kansas City, 2015), 133; Christopher D. Geist, "The Slave's Friend: An Abolitionist Magazine for Children," American Periodicals 9 (1999): 30; Thomas F. Harwood, "The Abolitionist Image of Louisiana and Mississippi," Louisiana History 7 (1966): 284.

14 Harriet Martineau, Retrospect of Western Travel (London: Saunders and Otley, 1838), vol. II, 136.

15 The term "paternalism" has a long history within the study of slavery; an effective recent definition is that it is "white patriarchy wearing a sentimental mask to illustrate ... why white men should hold all the power; because they used it to care for all those 'dependents' incapable of caring for themselves" (Laurel Clark Shire, "Sentimental Racism and Sympathetic Paternalism: Feeling Like a Jacksonian," Journal of the Early Republic 39 [2019], 114). On obeah, see Diana Paton, The Cultural Politics of Obeah:Religion, Colonialism and Modernity in the Caribbean World (Cambridge, UK: Cambridge University Press, 2015) and Janelle Rodriques, Narratives of Obeah in West Indian Literature: Moving Through the Margins (New York: Routledge, 2019). 
resent, and who will help lead Jamaica into a bright post-Emancipation future. At the time that The White Witch of Rosehall was published, many Jamaicans, including some among the mixed-race bourgeoisie to which de Lisser belonged, were beginning to advocate independence from Britain, and the author worked to portray the island's past as including elements of both planter cruelty, as epitomized by Annie Palmer, and African savagery, as represented by Takoo. That neither element had triumphed was due, he claimed, to the wise and just dominion of the Empire, personified by Rutherford; should Jamaica reject British rule, he feared, one or both of these cultural traits might dominate the new nation.

In this argument, de Lisser echoed a long-standing critique of slavery as practiced in Jamaica in particular: that this society, to a degree beyond that of Britain's other plantation colonies, was so debauched and unstable that it failed to constrain its white female inhabitants, who were thus able to use their financial and erotic capital to dominate men of all races. As Lizabeth ParavisiniGebert notes, Annie Palmer's "sexual excesses and brutality" are "emblematic of the debasing power of the plantation system," which has permitted her to illegimately acquire a position of untrammeled power from which she commits acts which endanger the patriarchal system upon which slavery rests. While it was acceptable for slaveholding men to inhabit what the abolitionist James Ramsay called "the kingdom of I," a woman's comparable behavior seemed to pose a threat not only to the enslaved but to the colony itself. But as many white Jamaican men died young, due to the island's unhealthy physical environment and the perpetual temptation to overindulge in drinking, sex, and other pastimes, or spent much of their time in the metropole, it was not necessary for a white woman to become a "black widow" like Annie Palmer in order to gain control over a plantation and its workforce. ${ }^{17}$

17 Lizabeth Paravisini-Gebert, "The White Witch of Rosehall and the Legitimacy of Female Power in the Caribbean Plantation," Journal of West Indian Literature 4 (1990): 26, 31-32; Trevor Burnard, "Freedom, Migration, and the American Revolution," in Eliga H. Gould and Peter S. Onuf, eds., Empire and Nation: The American Revolution in the Atlantic World (Baltimore: Johns Hopkins University Press, 2005), 305. In the only major study of Jamaican female slaveholders, Christine Walker notes that these women's claims to masculine authority, including physical violence, "exceeded the bounds of an acceptable feminine force," yet at the same time their actions were crucial to the colony's economic success (Christine Walker, Jamaica Ladies: Female Slaveholders and the Creation of Britain's Atlantic Empire [Chapel Hill: University of North Carolina Press, 2020]), 126. See also Sarah E. Yeh, "'A Sink of All Filthiness': Gender, Family, and Identity in the British Atlantic, 16881763," The Historian 68 (2006): 66-88. 
Although in theory white women were civilizing agents whose presence in Jamaica rendered it more English, a counter-discourse developed in eighteenth-century British culture, one which asserted that West Indian white women were even crueler than their planter husbands, fathers, or sons, and which epitomized these colonial women's "distance from the socially legitimating status of 'lady." This malevolent image dissipated to an extent towards the end of the century, as the colonies and their inhabitants became ever richer, and many of the latter settled permanently in England, where they were seen as acquiring a degree of civility, to such an extent that West Indian heiresses became sought-after brides for impoverished aristocrats. ${ }^{18}$ But while pro-slavery advocates did their utmost to refute abolitionists' claims that male plantation owners were a blot upon the nation's conscience, they were quick to attribute the cruelty for which Jamaican slaveholders were so frequently criticized to women, arguing that the true offenders were females who had gained too much independence from male authority, and who tried to mask their innate physical and emotional frailty through appalling abuse of the enslaved. Annie Palmer's offences, from dressing as a man to murdering her husbands and enslaved sexual partners, fit easily within this paradigm of the morally and sexually deviant West Indian white woman who, if not constrained by a strong and honorable man, would soon fall into irreversible moral decline; even if she arrived upon the island "as chaste as a Vestal, she becomes in forty eight hours a perfect Messalina," and soon thereafter a "Jamaica Termagant" whose cruelty to the enslaved was such that "a Negro had better live in Hell" than within her power. Such hyperbolic assertions were borne out by the testimony of several white eyewitnesses to a House of Commons select committee on abolition, who in 1791 reported that they had observed a number of high-status white Jamaican women, including the wife of a prominent clergyman, pouring hot wax onto their slaves' bodies, or "abus[ing] [an enslaved woman] with cayenne pepper ... in a way too horrid and indecent to mention."19

18 Erin Mackie, "Jamaican Ladies and Tropical Charms," ARIEL: A Review of International English Literature 37 (2006), 19o; Jennifer Reed, "Moving Fortunes: Caribbean Women's Marriage, Mobility, and Money in the Novel of Sentiment," Eighteenth-Century Fiction $3^{1}$ (2019): 509.

19 William Pittis, The Jamaica Lady; or, The Life of Bavia (London: Thomas Bickerton, 1720), 35, 38; Inge Dornan, "'Madda! Madda! Yiera! Yiera!': African Women Slaves and the Abolition of the British Transatlantic Slave Trade," in David T. Gleeson and Simon Lewis, eds., Ambiguous Anniversary: The Bicentennial of the International Slave Trade Bans (Columbia: University of South Carolina Press, 2012), 83-84; An Abstract of the Evidence delivered before a Select Committee of the House of Commons, in the Years 1790, and 1791; on the Part of the Petitioners for the Abolition of the Slave-Trade, 2nd. ed. (London: James Phillips, 1792), 
While the story of Delphine Lalaurie was a boon to anti-slavery activists, it simultaneously permitted supporters of slavery to claim that the paternalist practice of slaveholding was indeed benign, and that it was Lalaurie's gender that was to blame for the fate of her slaves. Like Annie Palmer, she had married several times, and although she was never accused of involvement in her husbands' deaths, they allowed her to live for much of her life outside of patriarchal control. Her final spouse, Louis Lalaurie, was several decades younger than she was, and lacked both her wealth and her connections of kinship and friendship to New Orleans' Francophone elite; he was also widely depicted as having been dominated by his wife, and thus unable to properly subjugate her to his authority. Delphine was not dissimilar to many elite women in her city in the late eighteenth and early nineteenth centuries, who controlled their own fortunes and who, although they could not vote or hold office, used their position as society hostesses to influence the political life of the municipality. But by the 183os, the "Americans", most of whom were Anglo-Saxon Protestants, were becoming far more numerous and powerful, and they were disturbed by what they saw as the boldness and immodesty of elite French creole woman, whom they considered to exert themselves far too assertively in the public sphere. Some contemporary commentators on the Lalaurie case claimed that Delphine was innocent of the atrocities attributed to her, and that the story had been concocted and spread by the "Americans," who resented her powerful position in what they saw as "their" city, making her "the first victim of yellow journalism in this country." But her story could also be mobilized as a defense of slavery, as long as it was properly managed by men. Harriet Martineau claimed that such evil could occur because the institution of slavery gave white people the power to do as they pleased to their bondspeople, but Southerners riposted that male slaveholders were willing and able to restrain their passions and treat the enslaved in a firm but just manner. Delphine Lalaurie, a woman who had gained too much independence, and who represented a culture whose influence was waning, could thus be depicted as a terrible but unsurprising exception to the male-centred practice of slave management, rather than the norm. ${ }^{20}$

At the center of the Lalaurie and Palmer narratives are two women, one real, one fictional, who owe their notoriety to behavior that was considered unacceptable even by the standards of their fellow slaveholders in New Orleans and

75. See also Trevor Burnard and Deirdre Coleman, "The Savage Slave Mistress: Punishing Women in the British Caribbean, 1750-1834," Slavery \& Abolition (forthcoming).

$20 \quad$ Perez Castillo, “'Stones in the Quarry," 159; Fred R. Darkis, Jr., "Madame Lalaurie of New Orleans," Louisiana History 23 (1982): 388, 389; Morlas, "La Madame et la Mademoiselle," 122; Stanley Clisby Arthur, Old New Orleans (New Orleans: Harmanson, 1936), 147. 
Jamaica, the former the city at the end of America's "river of dark dreams" that by the 183 os was the nation's largest slave mart, and the latter an island long notorious among metropolitan Britons for the harshness of its slave system and the debauchery of its planter elite. ${ }^{21}$ Within the historiography of slavery in the Atlantic world, Lalaurie and Palmer are anomalies not only because of the extreme nature of their abuse of the enslaved, but also due to their gender. As women who supplanted their husbands and overseers and took control over the management of their slaves, they are historically significant because they call into question both academic and popular conceptions of slavery, which have been and largely remain centered on the assumption that the prototypical slaveholder, particularly a notably brutal one, was male. Before the 1980s, when Catherine Clinton and Elizabeth Fox-Genovese published, respectively, The Plantation Mistress and Within the Plantation Household, the historiography of North American and West Indian slavery was essentially silent on the topic of slaveholding women, who were assumed to have been as marginal to slave management as women of the urban North were to finance and industry. ${ }^{22}$ Female slaveholders made brief appearances in antebellum pro-slavery tracts, or in historical works produced by apologists for slavery, in the guise of the "plantation mistress," the maternalist counterpart to the paternalist planter. As idealized wives and mothers, these women were depicted as playing a role comparable to the "angel in the house," that archetype of nineteenth-century Anglo-American domesticity, but their maternal responsibilities supposedly extended beyond their families to the plantation community, and included nursing sick slaves and training enslaved children. As a genteel white woman, associated with altruism and piety, the plantation mistress might play a protective role towards the enslaved, interceding with a husband, brother, or father

21 The phrase is from Walter Johnson, River of Dark Dreams: Slavery and Empire in the Cotton Kingdom (Cambridge, MA: Harvard University Press, 2013). See also Harwood, "The Abolitionist Image of Louisiana and Mississippi."

22 Catherine Clinton, The Plantation Mistress: Woman's World in the Old South (New York: Pantheon, 1982); Elizabeth Fox-Genovese, Within the Plantation Household: Black and White Women of the Old South (Chapel Hill: University of North Carolina Press, 1988). Despite the recent publication of Stephanie E. Jones-Rogers' They Were Her Property: White Women as Slaveholders in the American South (New Haven: Yale University Press, 2019), the image and reality of the slaveholding woman remains underdeveloped within the historiography of the antebellum South, despite important work on this subject by, amongst others, Laura Edwards, Drew Gilpin Faust, Thavolia Glymph, Marli Weiner, and Kirsten Wood. Prior to the publication of Jones-Rogers' book, few scholars had expanded on Glymph's claim that "violence on the part of white women was integral to the making of slavery" (Thavolia Glymph, Out of the House of Bondage: The Transformation of the Plantation Household [Cambridge, UK: Cambridge University Press, 2008], ch. 1). 
to treat an erring bondsperson with mercy. At the same time, her innate feminine delicacy forestalled her from desiring, let alone taking, responsibility for an estate and its workforce in the absence of white men; with regard to the enslaved population, a female slaveholder was described as more likely to be the victim of violence than its perpetrator. ${ }^{23}$

In light of this discussion of the sources of the legends regarding Annie Palmer and Delphine Lalaurie, the historical contexts in which they emerged, and the extent to which these women have become ever more widely known in recent years, the question arises not of how but of why these stories continue to circulate, and to capture the attention not only of tourists and promoters of tourism, but of a wide array of creatives. What cultural work do these stories perform, and why are many people eager to consume them in so many formats?

At the most basic level, these stories are, literally, sensational. Steeped in transgressive violence, they center on the stark contrasts between the villains and their victims - rich white women and the enslaved people who occupied the lowest level of New Orleanian or Jamaican society, and could not protect themselves from the terror these women inflicted upon them. ${ }^{25}$ These distinctions are encapsulated in one novelist's description of Delphine Lalaurie's "lovely white hands," which were the sign of a true Southern lady and were on view at her elegant soirees, "flashing with their emerald rings," but which "sometimes were used for harsher purposes than for lifting her crystal liqueur glass to her lips." ${ }^{26}$ They also respond and contribute to the phenomenon of "dark tourism" and its offshoot, "ghost tourism," which conceptualize sites associated with enslavement as places of forbidden fascination, redolent with histories of transgressive behavior-interracial sexual relationships; savage physical

23 See, for example, Kirsten E. Wood, "Broken Reeds and Competent Farmers: Slaveholding Widows in the Southeastern United States," Journal of Women's History 13 (2001): 34-57.

24 The title of this section is adapted from Bram Dijkstra, Idols of Perversity: Fantasies of Feminine Evil in Fin-de-Siecle Culture (New York: Oxford University Press, 1988).

25 In her essay about the 1989 assault on the "Central Park Jogger," Joan Didion argued that sensational crime narratives frequently turn on "the demonstrable 'difference'” between victims and perpetrators; see Didion, "Sentimental Journeys," in Joan Didion, After Henry (New York: Simon \& Schuster, 1992), 82-83. It may be for this reason that Annie Palmer's murder of her husbands is a minor part of her legend in comparison with her treatment of enslaved people.

26 Saxon, Fabulous New Orleans, 206. 
punishments; African-derived magical practices; the innately horrific institution of slavery itself. ${ }^{27}$ Rose Hall's appeal as a venue for events such as weddings and conferences, as well as for Gothicized tourism, stems from its lurid presentation of the history of the "great house" as much as it does from the complex's luxurious facilities.

In recent years, historic sites such as Whitney Plantation have opened as tourist attractions focused on the experiences of the enslaved, and the Virginia plantations of presidents Thomas Jefferson (Monticello), James Madison (Montpelier), and George Washington (Mount Vernon) have reframed their historical interpretations to depict the "lives bound together" of their free and enslaved inhabitants. Nonetheless, some tourists are most comfortable with an approach which officially deplores the practice of slaveholding while encouraging visitors to admire what is presented as the gracious and leisurely lifestyle of the plantation elite, downplaying the fact that this way of life rested on the agricultural and domestic labors of enslaved people. While this variety of tourism is integral to sites such as the Louisiana River Road plantation Nottoway and to annual events like the Natchez Spring Pilgrimage, Rose Hall and 1140 Royal Street appeal not only to those who are fascinated by the ideal of gracious antebellum living, but to aficionados of "torture porn." 28 This genre of popular entertainment, which originated at the beginning of this century through several low-budget horror films, including Saw (2004) and Hostel (2005), combines graphic violence with aggressively sexual imagery, and often includes scenes in which a beautiful woman tortures or is tortured by a man. In the plantation context, it emphasizes the violence inherent in the relationship between slaveholders and bondspeople, recounting sometimes heavily fictionalized tales of rape and rebellion.

But the question still arises of how Palmer and Lalaurie's gender influences the way in which their practices of slave management are portrayed within popular culture and tourism. Even had Palmer been a real historical figure, her actions, as repugnant as they were, would not have rendered her the most obviously horrific figure in Jamaica's pre-Emancipation history, as those of several male historical figures challenge such an evaluation. Trevor Burnard

27 See, for example, Benjamin D' Harlingue, “On the Plantation with Ghosts: Antagonisms of Slavery Tourism," South Carolina Review 47 (2015): 75; see also Tiya Miles, Tales from the Haunted South:Dark Tourism and Memories of Slavery from the Civil War Era (Chapel Hill: University of North Carolina Press, 2015) and Alan Rice and Johanna Kardux, "Confronting the Ghostly Legacies of Slavery," Atlantic Studies 9 (2012): 245-272.

28 "Natchez Spring Pilgrimage" (https://natchezpilgrimage.com/spring-pilgrimage/), accessed 16 June 2020. 
has explored in depth the voluminous diaries kept between 1750 and 1786 by Thomas Thistlewood, an English overseer and, later, an independent planter in Jamaica, and has demonstrated that throughout his career Thistlewood transformed the estates he managed into "theater[s] of terror" through his constant round of physical punishments of and sexual assaults upon the enslaved. ${ }^{29}$ His actions, meticulously detailed in his diaries, went beyond the usual repertoire of harsh penalties which eighteenth-century Jamaicans enacted upon refractory slaves, and included "Derby's dose," a ritualistic chastisement in which a slave was forced to defecate into an offender's mouth, after which the latter was gagged for several hours. As Burnard has noted, punishments such as these "seem to have been devised more to humiliate [Thistlewood's] slaves and to demonstrate to his charges the gratuitous assertion of his total power than to correct them for ... misdemeanors," as epitomized by his decision, soon after he arrived at his first post as an overseer, to inflict 150 lashes upon an elderly enslaved man whom he claimed had assisted a runaway. ${ }^{30}$

While Thistlewood meticulously listed his rapes and tortures of the enslaved in terse, dry prose, the story of his contemporary, Dr Lewis Hutchinson, is not nearly as well documented. Hutchinson, owner of the Edinburgh Castle plantation in Jamaica's St Ann Parish, was hanged for murder in Spanish Town on 16 March 1773. He was sentenced to death for killing John Callender, one of a group of soldiers who had been sent to arrest him for his assault on another planter the previous year; when the men searched his house, they found dozens of watches and garments of mysterious provenance. Hutchinson's slaves claimed that their master was a serial killer who had for years preyed upon travelers who passed by the isolated plantation, shooting them, taking their valuables, and leaving their corpses in sinkholes or in the hollow trunk of a silk-cotton tree, after which vultures consumed their remains, destroying the evidence of these crimes. Still more lurid tales abounded of this "mad doctor"; some claimed that he drank his victims' blood, while others asserted that he had been joined in his exploits by a number of equally sadistic neighbors, men and women of outward respectability who enjoyed observing the death throes of those they killed.

Hutchinson's actions, real or reputed, were sufficient to afford him the nickname of "The Mad Master of Edinburgh Castle," whose alliteration and refer-

29 Trevor Burnard, "Theater of Terror: Domestic Violence in Thomas Thistlewood's Jamaica, 1750-1786," in Christine Daniels and Michael V. Kennedy, eds., Over the Threshold:Intimate Violence in Early America (New York: Routledge, 1999), 237.

3o Trevor Burnard, Mastery, Tyranny, and Desire: Thomas Thistlewood and His Slaves in the Anglo-Jamaican World (Chapel Hill: University of North Carolina Press, 2004), 261, 255. 
ence to a specific plantation are echoed in Annie Palmer's sobriquet "The White Witch of Rose Hall." ${ }^{31}$ But although there is no doubt as to Thistlewood's culpability as "the Jamaican Simon Legree," and, although many of the stories about Hutchinson are unverifiable (although they are presented as fact by the Library of Congress and the Jamaica National Heritage Trust) his murder of Callender is a matter of historical record, neither man has attracted the popular fascination so long accorded to Annie Palmer, although the Jamaican writer Kei Miller published a short poem about the "grave and terrible site" of Edinburgh Castle and its owner, the "Caribbean's first serial killer." While Palmer's legend is the basis for a highly profitable 250 -acre resort complex, whose facilities range from a convention center to a plant nursery, few tourists visit Edinburgh Castle, though the ruins of the house are open to visitors, and although Thistlewood has, through the work of Burnard and other historians, become far better known than many wealthier and more politically influential Jamaican slaveholders of his era, no public or private initiative has attempted to recreate sites associated with him as tourist lures. ${ }^{32}$

Similarly, the history of slavery in New Orleans, like that in Jamaica, includes a number of slaveholders who attracted public notice, and punishment, for their cruelty towards the enslaved. By Delphine Lalaurie's time, the city had become the centre of the United States' internal slave trade, a commerce in which those whom Frederick Douglass termed "human flesh-jobbers" satisfied the "lust, caprice and rapacity of the buyers and sellers of men."33 According to Edward E. Baptist, "in the sources that document the expansion of cotton production, you can find at one point or another almost every product sold in New Orleans stores converted into an instrument of torture [of the enslaved]," while Rashauna Johnson's study of slavery in early republican New Orleans depicts

31 Rebecca Tortello, "Lewis Hutchinson: The Mad Master," Jamaica Gleaner, undated (http:// old.jamaica-gleaner.com/pages/history/storyoo36.htm); “Edinburgh Castle," Jamaica National Heritage Trust (http://www.jnht.com/site_edinburgh_castle.php), both accessed 16 June 2020.

32 Miller, "Place Name: Edinburgh Castle," in Miller, The Cartographer Tries to Map a Way to Zion (Manchester, UK: Carcanet Press, 2014), 47; Larry Gragg, review of Burnard, Mastery, Tyranny, and Desire, H-Albion, April 2006 (https://www.h-net.org/reviews/showrev.php ?id=11615); "Rose Hall” (https://rosehall.com/), both accessed 16 June 2020. Literary scholar Jennifer Reed has constructed a set of digital maps of Thistlewood's property in Westmoreland Parish (Jennifer Reed, "'Sites of Terror' and Affective Geographies on Thomas Thistlewood's Breadnut Island Pen," Caribbeana: The Journal of the Early Caribbean Society 1 [2016]: 1-29).

33 Douglass, "What to the Slave is the Fourth of July?," 5 July 1852, Teaching American History (https://teachingamericanhistory.org/library/document/what-to-the-slave-is-the -fourth-of-july/), accessed 16 June 2020. 
the institution as "a system reliant on bodily torture." ${ }^{44}$ The antebellum records of the state's Supreme Court support these assertions, including as they do the 1849 case of State $v$. Morris, in which a slaveholder not only beat an enslaved man to death, but did so in such a "cruel and barbarous manner" that "a hole in the abdomen, the size of a dollar ... appeared to have been gouged out," and 1855's Kennedy v. Mason, in which the slave Jim Crack died after his overseer tied him to the frozen ground and beat him for ninety minutes with a whip and a hand-saw. ${ }^{35}$ In view of these and all too many other examples of the savage abuse of the enslaved by white New Orleanians, why has Delphine Lalaurie remained an icon of evil for two centuries?

The fact remains that while male slaveholders, ranging from Thomas Jefferson and George Washington to otherwise obscure men whose practices of slave management have been gleaned by historians from their journals and plantation papers, have been the subject of study for decades, the lives of individual women who owned and managed slaves remain largely unexplored, to such an extent that many otherwise well-informed people would struggle to name a female slaveholder, other than, perhaps, Gone With the Wind's fictional Scarlett O'Hara or Jane Eyre's Bertha Mason, the "madwoman in the attic." ${ }^{36}$ Could it be argued that the lurid legends of Annie Palmer and Delphine Lalaurie offer agency, albeit of a horrific variety, to these under-studied actors in the history of slavery? Could these women be seen as self-empowered individuals within societies in which even the richest and most socially elite white women had few arenas in which they could assert themselves, even if the methods they chose for such self-assertion were monstrous? The dominant image of the antebellum Southern white woman remains that of the charming but intellectually limited "belle," preoccupied with fashion and sociability, while West Indian creole women of the era before Emancipation were widely depicted as languid and

34 Edward Baptist, The Half Has Never Been Told: Slavery and the Making of American Capitalism (New York: Basic Books, 2014), 141; Rashauna Johnson, Slavery's Metropolis: Unfree Labour in New Orleans during the Age of Revolutions (New York: Cambridge University Press, 2016), 126.

35 Judith Kelleher Schafer, “'Details Are of a Most Revolting Character': Cruelty to Slaves as Seen in Appeals to the Supreme Court of Louisiana," Chicago-Kent Law Review 68 (1993): $1287-1288,1302$.

36 Delphine Lalaurie is almost unique among female slaveholders in being the subject of not one but two biographies, Carolyn Morrow Long's scholarly Madame Lalaurie: Mistress of the Haunted House (Gainesville:University Press of Florida, 2012) and Victoria Cosner Love and Lorelei Shannon's mass-market Mad Madame Lalaurie (Charleston:The History Press, 2011). 
indolent, due to the physical and social environment in which they lived. ${ }^{37}$ If Annie Palmer precipitated the deaths of her husbands, and if Delphine Lalaurie dominated her spouse to such an extent that he claimed to have had no inkling of the existence of her attic torture chamber, can they be regarded as unusually powerful women of their era, even if they chose to use that power for malevolent ends against the most vulnerable people in their societies? ${ }^{38}$

It is neither necessary nor possible to forgive the real crimes of Delphine Lalaurie or the fictive ones of Annie Palmer, but perhaps their misdeeds can be understood in a way which can encourage a more nuanced understanding of the experiences of white women in slave management. Those who spent the majority of their lives on isolated plantations were frequently lonely, and felt simultaneously overburdened with their domestic responsibilities and bored in the absence of those diversions, from shopping to charitable activities, which were available to urban women. Some, as described by Harriet Jacobs in Incidents in the Life of a Slave Girl and by Solomon Northup in Twelve Years a Slave, became bitterly envious of young, attractive female slaves whom they viewed as competitors for their husbands' sexual interest, and were emotionally or physically abusive towards these girls and women; as the Scottish soldier-turnedpoet John Marjoribanks wrote of white Jamaican women, "a jealous mistress finds a ready sham/To give a handsome maid the sugar dram," thus removing a rival with poison. ${ }^{39}$ While antebellum Southern society insisted that the region's elite white women were innately more docile and refined than those of the North, abolitionists claimed that children, girls as well as boys, who were raised by and became slaveholders never learned to restrain their passions, and thus, in Burnard's phrase, they "found it difficult not to be tyrants in all their relationships." 40

White boys and men in the West Indies and the United States could release their aggressions through military service, hunting, sport, gambling, or sexual liaisons, but girls and women were barred from these activities, and were expected to exist within very narrow social and emotional parameters; lacking the empowerment that urban females could gain through philanthropy, education, or civic activism, they could vent their frustrations only upon the

\footnotetext{
37 Wylie Sypher, "The West-Indian as a 'Character' in the Eighteenth Century," Studies in Philology 36 (1939): 503 .

38 Jennifer Donahue, "The Ghost of Annie Palmer: Giving Voice to Jamaica's 'White Witch of Rose Hall', Journal of Commonwealth Literature 49 (2014): 245.

39 John Marjoribanks, Slavery: An Essay in Verse (1791), in Marcus Wood, ed., The Poetry of Slavery: An Anglo-American Anthology, 1764-1865 (Oxford: Oxford University Press, 2003), 201.

Burnard, "Theater of Terror," 244.
} 
enslaved. A metropolitan French visitor to Louisiana in the early nineteenth century warned his readers that creole women were devoid of self-restraint; while their "slow and languid gait" indicated their "apathetic indolence," should a slave attract their ire, "in an instant they are armed with a formidable whip; it is no longer the arm that cannot sustain the weight of a shawl or reticule." ${ }^{41}$ Similarly, in the abolitionist anthology America Slavery As It Is, co-editor Theodore Dwight Weld stated that slaveholding women possessed the emotional sensitivity associated with genteel femininity, but not the necessary selfcontrol; "their sensibility changed to fury must needs feed itself for a while on the hideous spectacle; they must, as to revive themselves, hear the piercing shrieks, and see the flow of fresh blood; there are some of them who, in their frantic rage, pinch and bite their victims," transforming themselves from delicate ladies into savage beasts. ${ }^{42}$ While the institution of slavery generated the wealth that allowed some white women to become "ladies," the social formations that it created placed so many restrictions upon these women that many spent their adult lives mostly bored and dissatisfied, and these emotions sometimes caused them to ignore society's demand that they behave at all times as "innocent of any hint of hunger, temper, or passion," encouraging them to treat enslaved people with exceptional harshness and, sometimes, appalling cruelty. In situations in which the death or absence of a male authority figure left them in charge of the management of the enslaved, it is alarming but not entirely surprising that in some instances these women treated their bondspeople with as much violence as male masters and overseers did. ${ }^{43}$

41 Jean-Baptiste-Claude Robin, Voyage dans l'interieur de la Louisiane (Paris: F. Buisson, 1807), quoted in the Anti-Slavery Record, October 1836, 8-10.

42 Quoted in Karen Halttunen, "Humanitarianism and the Pornography of Pain in AngloAmerican Culture," American Historical Review 100 (1995): 324. Jones-Rogers observes that white girls who grew up on antebellum Southern plantations were socialized to accept and, in some instances, to perpetrate violence against the enslaved, just as their brothers were (Jones-Rogers, They Were Her Property, 7-11). See also Thomas A. Foster, Rethinking Rufus: Sexual Violations of Enslaved Men (Athens: University of Georgia Press, 2019), esp. ch. 4.

43 Fox-Genovese, Within the Plantation Household, 196-197. Anya Jabour documents the feelings of loneliness and boredom experienced by plantation owners' wives and daughters, who complained of a frequent "want of Society" which often left them feeling "very dull"; see Jabour, Scarlett's Sisters: Young Women in the Old South (Chapel Hill: University of North Carolina Press, 2007), 88. 
Despite the sometimes unnerving fascination that many tourists, television viewers, readers, et al. show for Annie Palmer and Delphine Lalaurie, and specifically with the horrifying acts of abuse with which their names have become synonymous, these stories support a belief which echoes that of many antebellum defenders of slavery, that it was these individuals who were evil, rather than the institution of slavery itself. As a result, the "Gothic excesses" of their narratives "obscure the colonial evils that Gothic conventions served to expose so well" elsewhere in these texts. These legends can be read as "aberration [s] from the paternalism that usually prevented such cruelty"; as anomalous cases of atrocities committed by individuals who, despite their wealth and social status, stood outside of the mainstream of the societies in which they lived. ${ }^{44}$ Annie Palmer was supposedly of Irish heritage and Haitian birth, and her true "parent" was an African voodoo practitioner, while Delphine Lalaurie was a French Catholic in a city that by the 183 os was becoming ever more Anglo-Saxon and Protestant, and the French Quarter in which she lived was "practically a foreign city surrounded by the United States." And, of course, both were assertive women in societies in which females were expected to be perpetually docile and demure. ${ }^{45}$ These societies themselves, Jamaica and New Orleans, could be viewed as the cultural frontiers of Atlantic slavery, marked by every sort of physical excess, in contrast to the supposedly "civilized" slavebased societies which had evolved in Barbados or Virginia. And the fact that, even in these supposedly corrupt and corrupting locales, these women were execrated for their actions, transformed into the villainesses of Gothic horror stories, and subjected to physical or social death, implies that their acts were aberrant and universally deplored by those who were well-versed in the proper management of slaves. Finally, the assertions on the part of both historical and contemporary observers that Palmer's and Lalaurie's torture and murder of enslaved people was unacceptable specifically because it was motivated by sadism, or perhaps insanity, rather than as punishment for the victims' mis-

44 Lizabeth Paravisini-Gebert, "Colonial and Postcolonial Gothic: The Caribbean," in Jerrold E. Hogle, ed., The Cambridge Companion to Gothic Fiction (New York: Cambridge University Press, 2002), 238; Anthony J. Stanonis, Creating the Big Easy: New Orleans and the Emergence of Modern Tourism, 1918-1945 (Athens: University of Georgia Press, 2006), 225; Colin Dickey, Ghostland: An American History in Haunted Places (New York: Viking Press, 2016), 245 .

45 Darkis, "Madame Lalaurie of New Orleans," 389; Christopher Benfey, Degas in New Orleans: Encounters in the Creole World of Kate Chopin and George Washington Cable (Berkeley: University of California Press, 1997), 37. 
behaviour, implies that, at least under some circumstances, extreme physical abuse and even killing could be considered legitimate strategies in the management of enslaved laborers. ${ }^{46}$

Finally, there is the problem inherent within these stories: they tend to have overly neat endings. Catharsis is valuable in interpersonal relationships, and in fictional narratives, but it is often problematic when invoked with respect to historical examples. The conclusions of the stories of Delphine Lalaurie and Annie Palmer-the one exiled from the only place that she had ever called home, and in which her family had been prominent for generations, the other murdered by a former slave through African sorcery-are satisfying when they are interpreted as the wages of sin, but they allow both the producers and the consumers of these narratives to feel that justice has been done, that the monsters have been destroyed and the social balance restored. These vicious female slaveholders, women who were aberrant even within their own historical contexts, let alone that of today, "embod[ying] both failed feminine socialization as well as a racial prejudice that is perceived by white audiences to have long since passed," have been served their just desserts, and those who enjoy learning about them can reassure themselves that they have nothing in common with such creatures, and that such monstrous acts could never occur today. ${ }^{47}$ Thus, there is no need to think more deeply about the experiences of those who were lucky enough not to have been enslaved at Rose Hall or at 1140 Royal Street, but whose lives were nonetheless damaged or destroyed by the actions of less notoriously cruel managers of slaves, male or female. Nor is it necessary to engage with Achille Mbembe's claim that, within the system of slavery "the slave is kept alive but in a state of injury, in a phantom-like world of horrors and intense cruelty," and that "slave life, in many ways, is a form of death-in-life."48 The stories have reached their conclusions, and those who have taken the Rose Hall ghost tour or loitered at the corner of Royal and Governor Nicholls streets can leave the premises with their selfies without feeling a need to consider the ways in which the economic, social, and political contexts of Atlantic slavery permitted the occurrence of such atrocities, let alone how the history of slavery continues to influence racial relations in the United States and postcolonial social and economic development in the Caribbean. As Tiya Miles has argued in her analysis of "ghost tours" at Southern plantations, it is possible to imagine "a different kind of social haunting," one which offers "recollection of past

46 This claim is borne out by the legal records of the antebellum South; see, for example, Schafer, “'Details', passim.

47 Christian, "Using the Past to Recuperate the Present," 1102.

48 Achille Mbembe, "Necropolitics," Public Culture 15 (2003): 21; italics in original. 
wrongs and warn[s] against the repetition of injustice in the future." ${ }^{49}$ But as long the Palmer and Lalaurie stories and their ever more numerous cultural representations continue to revel in the spectacle of individualized evil, and present their protagonists as women trying, and failing, to do a man's business of managing enslaved people, they will occlude the considerably less spectacular but far more evil systems that produced them. As the articles in this issue make clear, slave management, whether practiced by men or by women, was in many instances sufficiently cruel that it needs no Gothic enhancement for its horror to become apparent.

\section{Works Cited}

An Abstract of the Evidence delivered before a Select Committee of the House of Commons, in the Years 1790, and 1791; on the Part of the Petitioners for the Abolition of the SlaveTrade, 2nd. ed. London: James Phillips, 1792.

Arthur, Stanley Clisby. Old New Orleans. New Orleans: Harmanson, 1936.

Baptist, Edward E. The Half Has Never Been Told: Slavery and the Making of American Capitalism. New York: Basic Books, 2014.

Benfey, Christopher. Degas in New Orleans: Encounters in the Creole World of Kate Chopin and George Washington Cable. Berkeley: University of California Press, 1997. Blassingame, John. Black New Orleans, 1860-1880. Chicago: University of Chicago Press, 1973.

Burnard, Trevor. "Freedom, Migration, and the American Revolution." In Eliga H. Gould and Peter S. Onuf, eds., Empire and Nation: The American Revolution in the Atlantic World. Baltimore: Johns Hopkins University Press, 2005.

Burnard, Trevor. Mastery, Tyranny, and Desire: Thomas Thistlewood and His Slaves in the Anglo-Jamaican World. Chapel Hill: University of North Carolina Press, 2004.

Burnard, Trevor. "Theater of Terror: Domestic Violence in Thomas Thistlewood's Jamaica, 1750-1786." In Christine Daniels and Michael V. Kennedy, eds., Over the Threshold: Intimate Violence in Early America. New York: Routledge, 1999.

Burnard, Trevor, and Deirdre Coleman. "The Savage Slave Mistress: Punishing Women in the British Caribbean, 1750-1834." Slavery \& Abolition (forthcoming).

Cable, George Washington. "The Haunted House in Royal Street." In Cable, Strange True Stories of New Orleans. New York: Charles Scribner's Sons, 1889.

Castellanos, Henry C. “A Tale of Slavery Times." In Henry C. Castellanos, New Orleans As

49 Tiya Miles, "Goat Bones in the Basement: A Case of Race, Gender and Haunting in Old Savannah," South Carolina Review 47 (2015): 34. 
It Was: Episodes of Louisiana Life, ed. Judith Kelleher Schafer. Baton Rouge: Louisiana State University Press, 2006 (originally published 1895).

Castillo, Susan Perez. "'Stones in the Quarry' and Fiction in George Washington Cable's Strange True Stories of Louisiana." Southern Literary Journal 31 (1999): 19-34.

Christian, Tiffany A. "Using the Past to Recuperate the Present: The Authentic Evil of Madame Delphine Lalaurie in American Horror Story: Coven." Journal of Popular Culture $5^{2}$ (2019): 1101-1119.

Clinton, Catherine. The Plantation Mistress: Woman's World in the Old South. New York: Pantheon, 1982.

Darkis, Fred R. Jr. "Madame Lalaurie of New Orleans." Louisiana History 23 (1982): 383399 .

de Lavigne, Jeanne. Ghost Stories of Old New Orleans. New York: Rinehart and Company, Inc., 1946.

“Delphine LaLaurie." Wikipedia [https://en.wikipedia.org/wiki/Delphine_LaLaurie], accessed 16 June 2020.

"Delphine Lalaurie: Monster of Royal Street" (https://www.youtube.com/watch?v= HKJE2JqkRrQ); accessed 16 June 2020.

D'Harlingue, Benjamin. “On the Plantation with Ghosts: Antagonisms of Slavery Tourism." South Carolina Review 47 (2015): 74-92.

Didion, Joan. “Sentimental Journeys.” In Didion, After Henry. New York: Simon \& Schuster, 1992.

Dijkstra, Bram. Idols of Perversity: Fantasies of Feminine Evil in Fin-de-Siecle Culture. New York: Oxford University Press, 1988.

Dickey, Colin. Ghostland: An American History in Haunted Places. New York: Viking Press, 2016.

Donahue, Jennifer. “The Ghost of Annie Palmer: Giving Voice to Jamaica's 'White Witch of Rose Hall'" Journal of Commonwealth Literature 49 (2014): 243-256.

Dornan, Inge. “'Madda! Madda! Yiera! Yiera!': African Women Slaves and the Abolition of the British Transatlantic Slave Trade." In David T. Gleeson and Simon Lewis, eds., Ambiguous Anniversary: The Bicentennial of the International Slave Trade Bans. Columbia: University of South Carolina Press, 2012.

Douglass, Frederick. "What to the Slave is the Fourth of July?, 5 July 1852. Teaching American History (https://teachingamericanhistory.org/library/document/what-to -the-slave-is-the-fourth-of-july/), accessed 16 June 2020.

“Edinburgh Castle," Jamaica National Heritage Trust (http://www.jnht.com/site_edin burgh_castle.php), accessed 16 June 2020.

"Epitaph-Plate of 'Haunted' House Owner Found Here: Marble Cutter's Discovery Starts New Talk of Madame Lalaurie." New Orleans Times-Picayune, 28 January 1941.

Faber, Eberhard L. Building the Land of Dreams: New Orleans and the Transformation of Early America. Princeton, NJ: Princeton University Press, 2016. 
Fay, Jennifer. “Dead Subjectivity: White Zombie, Black Baghdad." cr: The New Centennial Review 8 (2008): 81-101.

Foster, Thomas A. Rethinking Rufus: Sexual Violations of Enslaved Men. Athens: University of Georgia Press, 2019.

Fox-Genovese, Elizabeth. Within the Plantation Household: Black and White Women of the Old South. Chapel Hill: University of North Carolina Press, 1988.

Geist, Christopher D. “The Slave's Friend: An Abolitionist Magazine for Children.” American Periodicals 9 (1999): 27-35.

Ghost Hunters International: The Legend of Rose Hall, series 2, episode 13 (first aired 17 February 2010) (https://www.youtube.com/watch?v=PJ8Noa64ls4); accessed 16 June 2020.

Glymph, Thavolia. Out of the House of Bondage: The Transformation of the Plantation Household. Cambridge, UK: Cambridge University Press, 2008.

Gragg, Larry. Review of Burnard, Mastery, Tyranny, and Desire. H-Albion, April 2006 (https://www.h-net.org/reviews/showrev.php?id=11615).

Halttunen, Karen. "Humanitarianism and the Pornography of Pain in Anglo-American Culture." American Historical Review 100 (1995): 303-334.

Harwood, Thomas F. “The Abolitionist Image of Louisiana and Mississippi." Louisiana History 7 (1966): 281-308.

"Hon. John Palmer." Legacies of British Slave-Ownership [https://www.ucl.ac.uk/lbs/ person/view/2146644535], accessed 16 June 2020.

Huston, Kristin Nicole. “Something At Least Human': Transatlantic (Re)Presentations of Creole Women in Nineteenth-Century Literature and Culture." PhD thesis, University of Missouri-Kansas City, 2015.

Jabour, Anya. Scarlett's Sisters: Young Women in the Old South. Chapel Hill: University of North Carolina Press, 2007.

Johnson, Rashauna. Slavery's Metropolis: Unfree Labour in New Orleans during the Age of Revolutions. New York: Cambridge University Press, 2016.

Johnson, Walter. River of Dark Dreams: Slavery and Empire in the Cotton Kingdom. Cambridge, MA: Harvard University Press, 2013.

Jones-Rogers, Stephanie E. They Were Her Property: Property: White Women as Slaveholders in the American South. New Haven: Yale University Press, 2019.

King, Grace. Creole Families of New Orleans. New York: The Macmillan Company, 1921.

Lomas, Laura. "Mystifying Mystery: Inscriptions of the Oral in the Legend of Rose Hall." Journal of West Indian Literature 6 (1994): 70-87.

Long, Carolyn Morrow. Madame Lalaurie: Mistress of the Haunted House. Gainesville: University Press of Florida, 2012.

Love, Victoria Cosner, and Lorelei Shannon. Mad Madame Lalaurie. Charleston: The History Press, 2011. 
Mackie, Erin. "Jamaican Ladies and Tropical Charms." ARIEL: A Review of International English Literature 37 (2006): 189-219.

Marjoribanks, John. Slavery: An Essay in Verse (1791). In Marcus Wood, ed., The Poetry of Slavery: An Anglo-American Anthology, 1764-1865. Oxford: Oxford University Press, 2003.

Martineau, Harriet. Retrospect of Western Travel. London: Saunders and Otley, 1838.

Mbembe, Achille. "Necropolitics," Public Culture 15 (2003): 11-40.

Miles, Tiya. "Goat Bones in the Basement: A Case of Race, Gender and Haunting in Old Savannah." South Carolina Review 47 (2015): 25-36.

Miles, Tiya. Tales from the Haunted South: Dark Tourism and Memories of Slavery from the Civil War Era. Chapel Hill: University of North Carolina Press, 2015.

Miller, Kei. “Place Name: Edinburgh Castle." In Miller, The Cartographer Tries to Map a Way to Zion. Manchester, UK: Carcanet Press, 2014.

Morlas, Katy Francis. "La Madame et la Mademoiselle: Creole Women in Louisiana, 1718-1865." MA thesis, Louisiana State University, 2005.

"Natchez Spring Pilgrimage" (https://natchezpilgrimage.com/spring-pilgrimage/), accessed 16 June 2020.

Nettleford, Rex, et al. Rose Hall, Jamaica: Story of a People, a Legend, and a Legacy. Rose Hall, Jamaica: Rose Hall Ltd., 1973.

Paravisini-Gebert, Lizabeth. "Colonial and Postcolonial Gothic: The Caribbean." In Jerrold E. Hogle, ed., The Cambridge Companion to Gothic Fiction. New York: Cambridge University Press, 2002.

Paravisini-Gebert, Lizabeth. "The White Witch of Rosehall and the Legitimacy of Female Power in the Caribbean Plantation." Journal of West Indian Literature 4 (1990): 25-45.

Paton, Diana. The Cultural Politics of Obeah: Religion, Colonialism and Modernity in the Caribbean World. Cambridge, UK: Cambridge University Press, 2015.

Pittis, William. The Jamaica Lady; or, The Life of Bavia. London: Thomas Bickerton, 1720.

Points, Marie Louise. The Haunted House: Its Interesting History and a Strange Romance. Chicago: The Craig Press, 1893.

Reed, Jennifer. “Moving Fortunes: Caribbean Women's Marriage, Mobility, and Money in the Novel of Sentiment." Eighteenth-Century Fiction 31 (2019): 509-528.

Reed, Jennifer. “'Sites of Terror' and Affective Geographies on Thomas Thistlewood's Breadnut Island Pen." Caribbeana: The Journal of the Early Caribbean Society 1 (2016): $1-29$.

Rice, Alan, and Johanna Kardux. "Confronting the Ghostly Legacies of Slavery." Atlantic Studies 9 (2012): 245-272.

Robin, Jean-Baptiste-Claude. Voyage dans l'interieur de la Louisiane. Paris: F. Buisson, 1807 . 
Rodriques, Janelle. Narratives of Obeah in West Indian Literature: Moving Through the Margins. New York: Routledge, 2019.

"Rose Hall" (https://rosehall.com/), accessed 16 June 2020.

Rose Hall Great House Haunted Night Tour (https://rosehall.com/tours/), accessed 16 June 2020.

Rosenberg, Leah. "Tourism and the Birth of Jamaican Literature." Jamaica Journal 32 (2015): 46-51.

Saxon, Lyle. Fabulous New Orleans. Gretna, LA: Pelican Publishing Company, 1988 (originally published 1928).

Schafer, Judith Kelleher. “'Details Are of a Most Revolting Character': Cruelty to Slaves as Seen in Appeals to the Supreme Court of Louisiana." In Paul Finkelman, ed., Slavery and the Law. Madison, WI: Madison House 1997.

Shire, Laurel Clark. "Sentimental Racism and Sympathetic Paternalism: Feeling Like a Jacksonian." Journal of the Early Republic 39 (2019): 111-122.

Smith, Felipe. "The Economics of Enchantment: Two Montego Bay, Jamaica Great House Tours." In Lowell Fiet and Janette Becera, eds., Caribbean 2000: Cultural (Con)Fusion. San Juan: University of Puerto Rico Press, 2000.

Stanonis, Anthony J. Creating the Big Easy: New Orleans and the Emergence of Modern Tourism, 1918-1945. Athens: University of Georgia Press, 2006.

"Summary." Providence Patriot, 3 May 1834.

Sypher, Wylie. “The West-Indian as a 'Character' in the Eighteenth Century." Studies in Philology 36 (1939): 503-520.

Tallant, Robert. The Romantic New Orleanians. New York: E.P. Dutton \& Co., Inc., $195^{\circ}$. Tortello, Rebecca. "Lewis Hutchinson: The Mad Master." Jamaica Gleaner, undated.

Waddell, Hope Masterson. Twenty-Nine Years in the West Indies and Central Africa: A Review of Missionary Work and Adventure, 1829-1858. London: T. Nelson and Sons, 1863.

Walker, Christine. Jamaica Ladies: Female Slaveholders and the Creation of Britain's Atlantic Empire. Chapel Hill: University of North Carolina Press, $202 \mathrm{O}$.

Wood, Kirsten E. "Broken Reeds and Competent Farmers: Slaveholding Widows in the Southeastern United States." Journal of Women's History 13 (2001): 34-57.

Yeh, Sarah E. "AA Sink of All Filthiness': Gender, Family, and Identity in the British Atlantic, 1688-1763." The Historian 68 (2006): 66-88. 